\title{
Experiences and management of physician psychological symptoms during infectious disease outbreaks: a rapid review
}

\author{
Kirsten M. Fiest ${ }^{1,2,3^{*}+}$ D, Jeanna Parsons Leigh ${ }^{3,4 \dagger}$, Karla D. Krewulak', Kara M. Plotnikoff ${ }^{1}$, Laryssa G. Kemp ${ }^{1}$,
} Joshua Ng-Kamstra ${ }^{1}$ and Henry T. Stelfox ${ }^{1,2,3}$

\begin{abstract}
Background: Prior to the COVID-19 pandemic, physicians experienced unprecedented levels of burnout. The uncertainty of the ongoing COVID-19 pandemic along with increased workload and difficult medical triage decisions may lead to a further decline in physician psychological health.

Methods: We searched Medline, EMBASE, and PsycINFO for primary research from database inception (Medline [1946], EMBASE [1974], PsycINFO [1806]) to November 17, 2020. Titles and abstracts were screened by one of three reviewers and full-text article screening and data abstraction were conducted independently, and in duplicate, by three reviewers.

Results: From 6223 unique citations, 480 articles were reviewed in full-text, with 193 studies (of 90,499 physicians) included in the final review. Studies reported on physician psychological symptoms and management during seven infectious disease outbreaks (severe acute respiratory syndrome [SARS], three strains of Influenza A virus [H1N1, H5N1, H7N9], Ebola, Middle East respiratory syndrome [MERS], and COVID-19) in 57 countries. Psychological symptoms of anxiety (14.3-92.3\%), stress (11.9-93.7\%), depression (17-80.5\%), post-traumatic stress disorder (13.275.2\%) and burnout (14.7-76\%) were commonly reported among physicians, regardless of infectious disease outbreak or country. Younger, female (vs. male), single (vs. married), early career physicians, and those providing direct care to infected patients were associated with worse psychological symptoms.

Interpretation: Physicians should be aware that psychological symptoms of anxiety, depression, fear and distress are common, manifest differently and self-management strategies to improve psychological well-being exist. Health systems should implement short and long-term psychological supports for physicians caring for patients with COVID-19.
\end{abstract}

Keywords: COVID-19, Mental health, Physicians, Review

\footnotetext{
* Correspondence: kmfiest@ucalgary.ca

Kirsten M. Fiest and Jeanna Parsons Leigh are co first author.

'Department of Critical Care Medicine, Cumming School of Medicine, University of Calgary \& Alberta Health Services, 3134 Hospital Drive NW Calgary T2N4Z6, Canada

2Department of Community Health Sciences, Cumming School of Medicine, University of Calgary, 3134 Hospital Drive NW, Calgary T2N4Z6, Canada Full list of author information is available at the end of the article
}

\section{Background}

Infectious disease outbreaks pose a severe threat to public health [1,2]. A novel infectious disease, Coronavirus Disease 2019 (COVID-19), has spread rapidly globally after its emergence in late 2019, prompting The World Health Organization to declare a pandemic [3]. The transmissibility and the severity of COVID-19 make this a particularly dangerous pathogen [4], and adds to

(c) The Author(s). 2021 Open Access This article is licensed under a Creative Commons Attribution 4.0 International License, which permits use, sharing, adaptation, distribution and reproduction in any medium or format, as long as you give appropriate credit to the original author(s) and the source, provide a link to the Creative Commons licence, and indicate if changes were made. The images or other third party material in this article are included in the article's Creative Commons licence, unless indicated otherwise in a credit line to the material. If material is not included in the article's Creative Commons licence and your intended use is not permitted by statutory regulation or exceeds the permitted use, you will need to obtain permission directly from the copyright holder. To view a copy of this licence, visit http://creativecommons.org/licenses/by/4.0/ The Creative Commons Public Domain Dedication waiver (http://creativecommons.org/publicdomain/zero/1.0/) applies to the data made available in this article, unless otherwise stated in a credit line to the data. 
frontline healthcare professionals experiencing concern, anxiety, frustration, and fear [5-8].

A recent rapid review of 59 papers described psychological outcomes of all healthcare professionals in response to infectious disease outbreaks (e.g., COVID-19, Ebola, H1N1, H7N9, MERS and SARS) and reported that healthcare professionals caring for affected patients experienced increased levels of acute or post-traumatic stress and psychological stress [9]. This rapid review included data from eight studies on psychological outcomes of healthcare professionals from China during the COVID-19 pandemic. However, our search retuned 174 studies specific to COVID-19. This reflects the growth of the pandemic, with over 200 countries reporting COVID-19 cases and over 19 million cases worldwide. The impact of the COVID-19 pandemic has varied from country to country, depending on the public health measures enacted in each country to minimize transmission.

Prior to the COVID-19 pandemic, studies reported that physicians experienced unprecedented levels of burnout [10-15]. Burnout among physicians is reported to be as high as 70\% [16], and has been reported to be higher than registered nurses (RNs) and respiratory therapists $[17,18]$. The uncertainty of the ongoing COVID-19 pandemic along with the moral distress, long shifts, and a unique role with difficult triage decisions, may further exacerbate a physician's mental well-being $[19,20]$. To date, experiences and management of physician psychological symptoms during the COVID-19 outbreak have not been comprehensively described and compared between countries and with previous infectious disease outbreaks. In response to this gap in the literature, we conducted a rapid review of the experiences and management of psychological symptoms in physicians during infectious disease outbreaks to better understand and support physician health during this unprecedented time.

\section{Methods}

We conducted a rapid review [21] to ensure timely synthesis of data in response to the COVID-19 pandemic. In the absence of a PRISMA statement for rapid reviews, we used the overall statement [22] to guide us where possible (Additional File 1) [23].

\section{Eligibility criteria}

Eligibility criteria were defined using the "Population, Exposure, Comparison, Outcomes, Study Designs" (PECOS) components.

\section{Population}

Physicians involved in caring for patients in any healthcare setting during an infectious disease outbreak. Due to the rapid nature of this review, other healthcare professionals were excluded.

\section{Exposure}

Caring for patients during an infectious disease outbreak. Care could be anticipated (e.g., not having worked a shift yet) or from direct patient care experiences.

\section{Comparators}

Any intervention, control group, or studies without a comparison group were eligible for inclusion.

\section{Outcomes}

Any outcome that measured physician psychological symptoms (e.g., fear, anxiety, stress) or ways to manage these experiences (e.g., behaviour changes) during infectious disease outbreaks.

\section{Study designs}

Any primary research of quantitative or qualitative design.

\section{Search strategy and selection criteria}

The search strategies were developed by a psychiatric epidemiologist (KMF), critical care physician (HTS), and a medical librarian. We searched Medline, EMBASE, and PsycINFO from inception until November 17, 2020. The final search strategy for Medline can be found in Additional File 2. No restrictions were placed on the language or date of publication.

Titles and abstracts were imported into Endnote X9 (Clarivate Analytics), which was also used to manage full-text articles. Inclusion criteria were as follows: 1) primary research (e.g., cross-sectional studies); 2) physicians as the target population; and 3) article describes experiences or management of psychological symptoms (e.g., anxiety, fear, stress) related to infectious disease outbreaks (e.g., COVID-19, SARS [Severe Acute Respiratory Disease Syndrome], H1N1). Exclusion criteria included: 1) studies of HIV or AIDS; and 2) physician perceptions or attitudes towards vaccination. Titles and abstracts were reviewed by one of three reviewers (KK, KP, LK) [24]. All abstracts selected by any reviewer moved onto the full-text stage. Full-text review was conducted independently and in duplicate. Disagreements (e.g., include/exclude article or reason for exclusion) were resolved by discussion or involvement of another reviewer as necessary.

\section{Data abstraction}

We abstracted data on publication (e.g., year of publication), study (e.g., location of data collection, setting, time of data collection), and participant characteristics (e.g., age, sex, specialty). Outcome data on experiences or 
management of physician psychological symptoms were also abstracted. The data abstraction form was developed and piloted by the study team. The data abstraction form, including quality assessment, was piloted on $10 \%$ of the included studies to ensure agreement. All data were abstracted independently and in duplicate. Any discrepancies between independently abstracted data were resolved by discussion or involvement of another reviewer as necessary. Data are reported using descriptive statistics.

\section{Study quality appraisal}

The quality of included quantitative studies was assessed using the Newcastle-Ottawa Scale, including the extension for cross-sectional studies $[25,26]$. This is an eight(cohort studies) or seven-item (cross-sectional studies) checklist. Studies were rated from 0 to 10 with a higher number indicating lower risk of bias and better study quality (very good: $9-10$ points; good: $7-8$ points; satisfactory: 5-6 points; unsatisfactory: 0 to 4 points). The Joanna Briggs Institute Checklist for Qualitative
Research was used to determine the quality of qualitative studies [27].

\section{Results}

\section{Literature search}

Following the removal of duplicates, the search yielded 6223 citations (Fig. 1). Of these, 480 articles were reviewed in full-text. The most common reasons for exclusion $(n=287)$ at the full-text stage were that the research was not primary research $(n=120)$, was not focused on physicians $(n=97)$, or not reporting on psychological symptoms associated with an infectious disease outbreak $(n=54)$. A total of 193 papers were included in the rapid review (Additional File 3) [28-89]. Most studies had a cross-sectional design $(n=181$, 93.8\%). All other study designs are listed in Additional File 3.

\section{Publication, study, and participant characteristics}

Of the 193 included studies (of 90,499 physicians), the majority focused on COVID-19 $(n=172$, published in $2020)$ or SARS $(n=13$, published between 2004 and

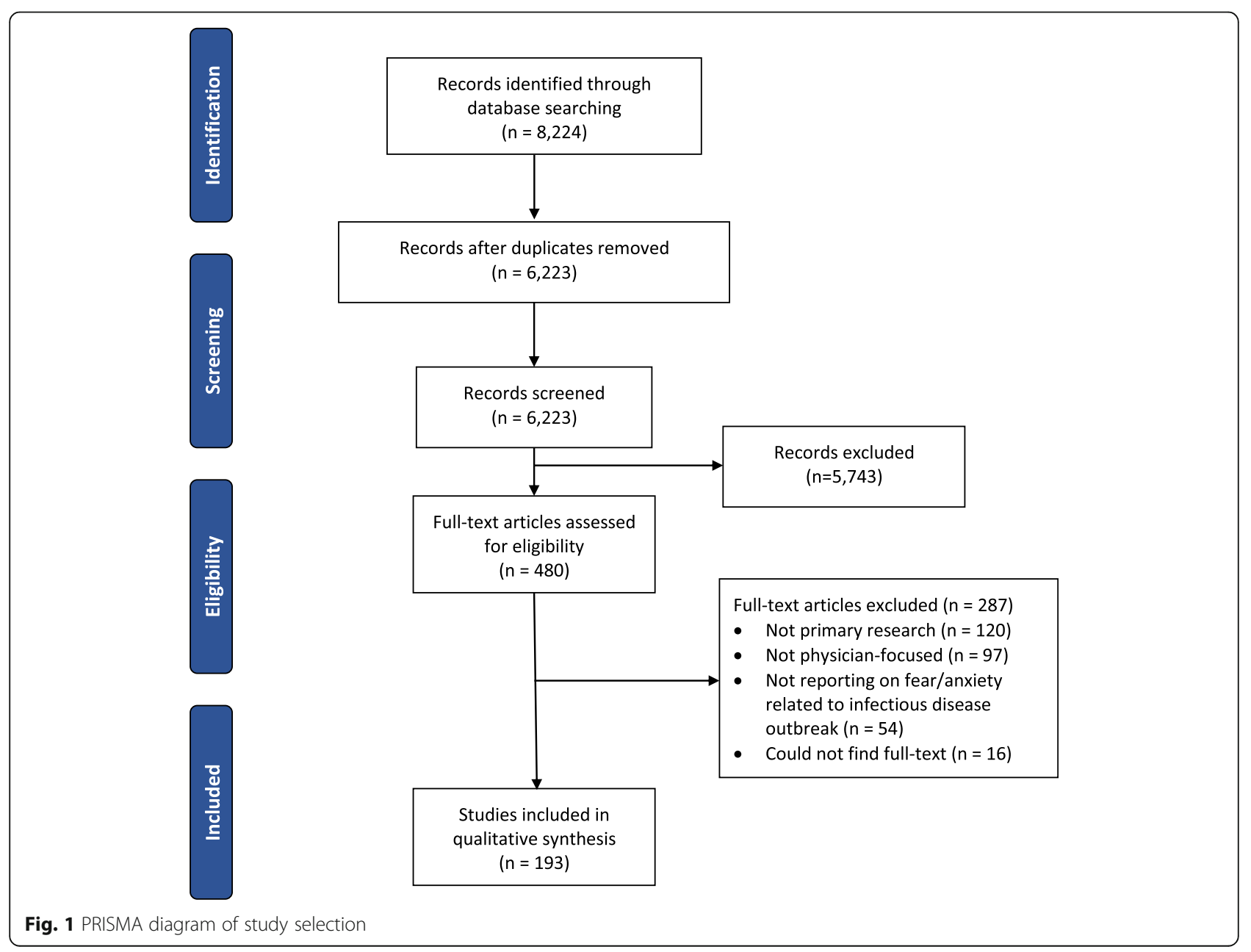


2009), followed by Influenza A virus $(n=5 ; n=2 \mathrm{H} 1 \mathrm{~N} 1$ [swine influenza], 2010-2011; $n=2 \mathrm{H} 5 \mathrm{~N} 1$ [avian influenza], 2008; $n=1$ H7N9 [avian influenza], 2017), Ebola ( $n=2$, published between 2016 and 2017), and Middle East Respiratory Syndrome (MERS) $(n=1,2019)$. Most included studies were conducted in Asia $(n=94)$ or North America $(n=30)$ [one study was conducted in both], Europe $(n=36)$, Africa $(n=8)$, South America $(n=4)$, Oceania $(n=3)$, collectively representing 57 different countries. Studies that focused on COVID-19 were conducted in 55 different countries from six different continents (Africa, Asia, Europe, North America, Oceania, South America) throughout the COVID-19 pandemic (Fig. 2) and included 87,667 physicians. Studies included physicians from a variety of settings and specialties (e.g., general practitioners, ICU, emergency room, urologists, oncologists, opthamologists, surgeons, etc.) (Additional File 3). Seventy studies reported on trainee physician (i.e., resident, fellow) experiences with psychological symptoms during infectious disease outbreaks.

\section{Experiences with physician psychological symptoms during infectious disease outbreaks}

All studies $(n=193)$ reported on physician experiences with psychological symptoms during infectious disease outbreaks, with consistent experiences reported across different disease outbreaks. The most common method to identify psychological symptoms (e.g., anxiety, depression, stress, isolation, worry, fear, stigma) was a validated questionnaire $(n=120)$ or survey $(n=91)$. The most common psychological symptoms measured with surveys or validated questionnaires reported included anxiety $(n=103)$, depression $(n=73)$, stress $(n=68)$, fear $(n=61)$, burnout $(n=25)$, mental distress/health $(n=$ $21)$, and post-traumatic stress disorder (PTSD) $(n=14)$ (Additional File 3). Most COVID-19 studies reported on physicians from USA $(n=23)[41,52,66,70,77,90-$
107], China $(n=22)[15,49,54-56,65,68,73,86,89$, $102,108-118]$ followed by India $(n=21)[40,50,58,63$, $67,71,102,119-132][41,52,66,70,77]$, Italy $(n=10)$ [32, 94, 102, 125, 133-138], and Turkey $(n=11)[35,44$, 94, 139-146] [28, 30, 32, 34, 36, 37, 42, 45, 47, 48, 59, 60, 62, 80, 87]. .Sixteen studies reported on physicians from multiple countries $[47,51,69,94,102,106,125$, 133, 147-154].

Ninety-seven $(97 / 172,56.4 \%)$ studies from 43 countries (most from China [ $n=17]$, USA, $[n=11]$, Turkey $[n=9]$, India $[n=8]$, Pakistan $[n=7]$, or Italy $[n=6])$ reported physician anxiety during the COVID-19 pandemic. Most studies used the Generalized Anxiety Disorder $(\mathrm{GAD}-2 / \mathrm{GAD}-7)(n=33)$, survey/interview $(n=26$, e.g., "Do you feel anxious when you case for COVID-19 patients" [35] or "Rate your level of anxiety regarding the COVID-19 outbreak on a scale of 1 to 10 [91]), Depression, Anxiety and Stress Scale-21 Items (DASS$21)(n=9)$, Hospital Anxiety and Depression Scale $(\operatorname{HADS})(n=9)$, State Trait Anxiety Inventory (STAI) (each $n=4$ ), along with other measurements (Additional File 3). The proportion of physicians who experienced symptoms of anxiety (i.e., any symptoms of anxiety measured on a validated scale [i.e., mild, moderate, and severe]) was reported in 34 studies, and ranged from 14.3\% (Iran) to $92.3 \%$ (Saudi Arabia and Egypt) (Fig. 3), with many individuals (9.8\% [India] to 39.3\% [Colombia]) having clinically significant symptoms (i.e., described as having clinically significant symptoms in the study or meeting the cut-off for clinically significant symptoms for the specific scale used [e.g., GAD-7 score $\geq 10]$ ). During other infectious disease outbreaks, the proportion of physicians with self-reported symptoms of anxiety related to the infectious disease outbreak ranged from $29.1 \%$ (SARS) to $67.0 \%$ (Ebola).

Seventy-two studies $(72 / 172,41.9 \%)$ from 37 countries (most from China $[n=12]$, India $[n=8]$, USA $[n=6]$, Turkey $[n=5]$, ) reported physician depression related to
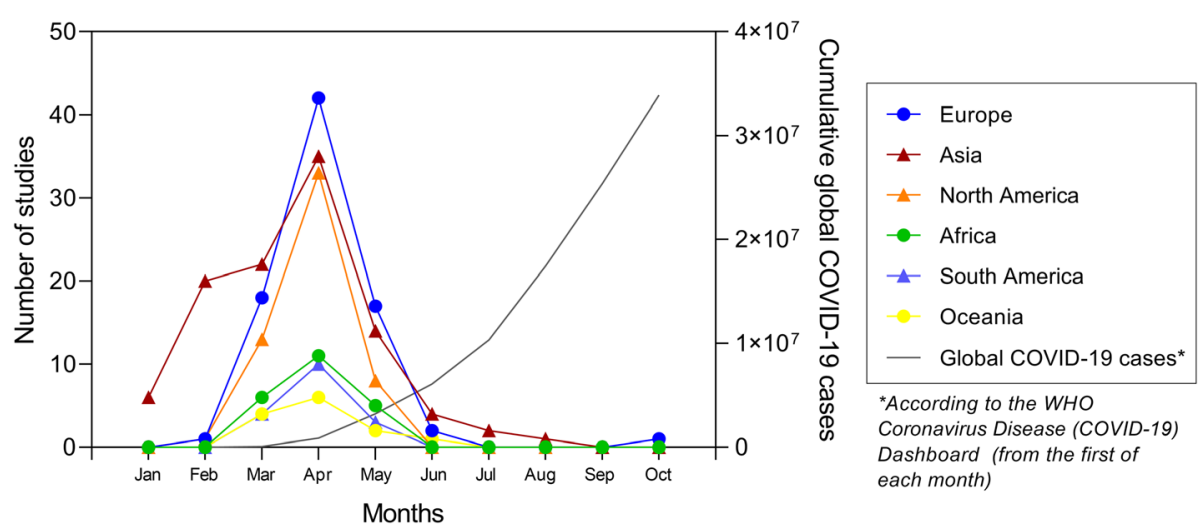

Fig. 2 Number of cumulative studies from different continents reporting on the psychological symptoms in physicians during the COVID-19 pandemic compared to the number of active global COVID-19 cases in 2020. Nineteen studies did not report a date range for data collection 


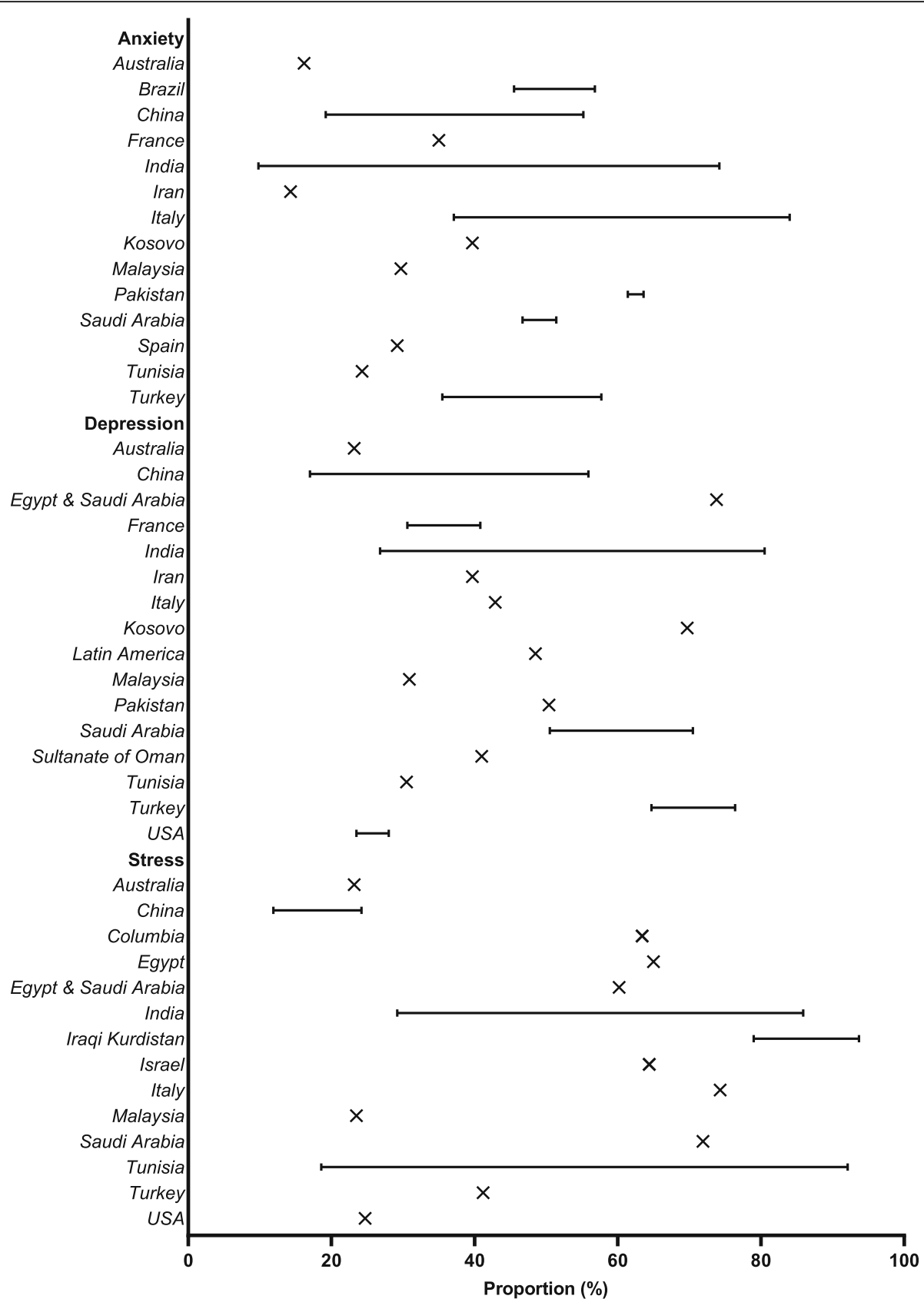

Fig. 3 Proportions of physicians experiencing COVID-19 related psychological symptoms (i.e., any symptoms of anxiety, depression, or stress measured on a validated scale [i.e., mild, moderate, and severe]) grouped by country

the COVID-19 pandemic. Most studies used the Patient Health Questionnaire-9 (PHQ-2/PHQ-4/PHQ-9) $(n=$ $31)$, DASS-21 $(n=10)$, survey $(n=9$, e.g.,"I feel depressed" [5-point Likert scale]), HADS $(n=9)$, along with other measurements (Additional File 3) [155]. The proportion of physicians who experienced symptoms of depression (i.e., any symptoms of depression measured on a validated scale [i.e., mild, moderate, and severe]) was reported in 31 studies, and ranged from 17\% (China) to $80.5 \%$ (India) (Fig. 3), with many individuals $(7.2 \%$
[China] to $62 \%$ [Turkey]) having clinically significant symptoms (i.e., described as having clinically significant symptoms in the study or meeting the cut-off for clinically significant symptoms for the specific scale used [e.g., PHQ-9 score $\geq 10]$ ). The proportion of physicians with self-reported symptoms of depression was not reported for other infectious disease outbreaks included in this review.

Sixty-four studies $(64 / 172,37.2 \%)$ from 33 countries (most from India $[n=13]$, USA $[n=9]$ ) reported on 
physician stress (Fig. 3) related to the COVID-19 pandemic. Most studies used a survey $(n=29$, e.g., "My daily life has become more stressful due to the COVID-19 pandemic" [156]), Patient Stress Scale (PSS-10, $n=17$ ), DASS-21 $(n=9)$, along with other measurements (Additional File 3). The proportion of physicians who experienced symptoms of stress (i.e., any symptoms of stress measured on a validated scale [i.e., mild, moderate, and severe]) was reported in 26 studies, and ranged from 11.9\% (China) to $93.7 \%$ (Iraqi Kurdistan) (Fig. 3). Symptoms of stress among physicians during other infectious disease outbreaks ranged from $31.8 \%$ (SARS) to $100 \%$ (Ebola).

Twenty-four studies from 12 countries reported on the proportion of physicians with symptoms of burnout related to the COVID-19 pandemic, which ranged from $14.7 \%$ (Canada) to $76 \%$ (Romania). Nine studies from seven countries reported on the proportion of physicians with symptoms of PTSD related to the COVID-19 pandemic, which ranged from $24.3 \%$ (China) to $75.2 \%$ (Turkey). Symptoms of PTSD and burnout were reported for other infectious disease outbreaks 13.2\% (SARS) and 36.4\% (H1N1), respectively.

Sixty-one studies reported on fear related to an infectious disease outbreak [29-31, 35-37, 43, 46, 53, 55, 61, 64, 72, 74, 78-83, 85-87, 94, 95, 99, 100, 107-109, 115, $117,119,123,128,131,132,134,142,146,147,155-$ 173]. Most of the studies $(n=52)$ reported physician's fear of infecting themselves or their family. The greatest sources of distress for emergency department physicians during SARS were the spread of the virus and the health of their family [83] and during the MERS outbreak, many Saudi Arabian physicians reported a great source of their anxiety was worry over their family acquiring the illness [31]. More than one-quarter (27.5\%) of academic physicians in Canada were concerned about SARS spreading to their family [46], while $89 \%$ of Egyptian physicians were concerned their family would contract H1N1 from them [43]. In Hong Kong, female physicians were more worried about infecting their families with SARS than male physicians [82]. Two months following the SARS outbreak, physicians reported that their greatest concern were fears of infecting self, family, and other loved ones [81]. Saudi Arabian physicians with past pandemic experience were less likely to experience fear during the COVID-19 pandemic [30].

\section{Factors associated with psychological symptoms during infectious disease outbreaks}

One hundred studies reported on factors associated with psychological symptoms during infectious disease outbreaks. Female sex (compared to male) was the factor most commonly associated with worse psychological symptoms in physicians $[30,41,44,48,63,66,71,77$,
$89,98,112,122,127,128,138,142,144,148,163,165$, $170,174-189]$. Other factors associated with poorer psychological outcomes included direct patient contact [28, $32,34,44,46,53,59,64,71,81,95,98,112,122,130$, 163, 169, 175, 182, 183, 186, 190-192] [30, 34, 41, 44, $48,59,63,66,71,77,89]$, single marital status (compared to married) $[39,44,59,63,98,122]$, younger age $[33,44,47,48,50,67,77,81,82,136,148,170,174,177$, $179,181,191,193-196]$, and more junior career stage (e.g., residents compared to staff) $[28,41,43,44,48,65$, 77, 100, 120, 122, 128, 129, 133, 136, 170, 174, 181, 185, 196, 197]. During COVID-19, feelings that there was inadequate PPE supply at their hospital was associated with worse psychological outcomes $[107,143,147,157$, $163,165,170,178,187,188]$. Physicians working more days, with higher patient volumes, or with increased duties than before than pandemic also had an increased prevalence of psychological symptoms [96, 101, 122, 128, 149, 187, 192, 195, 198]. Eighteen studies reported on insomnia $[32,35,36,54,65,69,88,114,128,145$, $149,163,175,177,181,188,192,194]$, which is associated with psychiatric disorders and is a risk factor for depression and anxiety [15, 32, 54, 65, 69, 199, 200]. During the SARS outbreak, physicians of Asian descent felt more stigmatized than their Caucasian colleagues (Canada) $[15,32,35,36,46,54,65,69,88,114,128,145$, $149,163,175,177,181,188,192,194,199,200]$.

Eleven studies [32, 54, 74, 81, 82, 84, 85, 94, 136, 143, 201] focused on the experiences of family physicians during infectious disease outbreaks. Family physicians practicing in Singapore during the H5N1 outbreak feared there would be inadequate staff to manage patient demand [85]. During the SARS outbreak, the majority of surveyed family physicians in both Hong Kong and Canada reported having no infection control training $(80 \%)$ and lacked confidence in dealing with SARS ( $70 \%)$. Many concerns centered around training, availability, and use of personal protective equipment (PPE). Family physicians felt they did not have sufficient training or experience with appropriate use of PPE, which they felt limited its effectiveness [74]. The shortage of PPE heightened their insecurities and some physicians recycled PPE or wore PPE for prolonged periods of time, which caused physical discomfort [74, 143]. Some family physicians reported not following protective procedures, such as hand washing or wearing gowns [82].

\section{Management of physician psychological symptoms during infectious disease outbreaks}

Nearly one-third ( $n=64,33.2 \%)$ of the studies evaluated ways physicians managed psychological symptoms during infectious disease outbreaks. Groups of physicians from several countries (China [108], India [40], Saudi Arabia [31], Egypt [43], Singapore [39, 74, 85], and Hong 
Kong [64]) reported voluntarily engaging in practices such as increased hand washing and wearing of PPE, even if it was not yet required by their workplaces $(n=$ 8). Recognition of service from the government was also indicated by physicians in China [108] and Singapore [53] as a positive buffer to experiencing negative psychological symptoms. Avoiding outbreak related news and social media was also reported by physicians in China $[56,108]$ and Saudi Arabia [30] $(n=3)$ conducted during the COVID-19 pandemic.

Physicians reported the importance of having social support from friends, family, colleagues, and professionals (e.g., counsellors) in 29 studies $[28,30,39,43$, $44,48,56,58,67,72,78,83,91,99,102,106,115,119$, 131, 150, 155, 163, 172, 192, 202-205]. Several studies $(n=29)$ described positive personal coping strategies such as maintaining a positive attitude and resilience [37, 46, 83, 100, 106, 108, 136, 202, 205, 206], practicing self-care (e.g., physical activity, eating well, resting, engaging in activities they enjoy) [30, 35, 56, 65, 70, 91, $102,103,117,119,129,131,150,151,207]$, and engaging with religious practices $[39,46,131,205]$ as a way to mitigate negative psychological outcomes. In contrast, two studies reported that physicians engaged in avoidance coping strategies (e.g., screaming, crying, denial, self-blame, disengaging, substance abuse, etc.) [83, 106, 108, 127, 202, 203, 205].

Specific to COVID-19, physicians in China [56], France [196], India [40, 50, 58], Pakistan [157, 192], South Korea [184], Tunisia [192], Turkey [44], and USA [99, 103, 105, 203] expressed desire for their organizations to provide access to psychological support through counselling programs or support hotlines $(n=13)$. Communication and appreciation from hospital administrators $(n=4)$ was indicated as an important gesture to help foster feelings of gratitude for physicians in China [108, 115], Colombia [201], and the USA [52] [52, 58, 62]. Physicians in China [108], France [28, 188], India [129], Israel [208], Pakistan [182], Saudi Arabia [30], Turkey [44], and the USA [52] indicated the importance of supportive workplace environments that provide an adequate supply of PPE, proper training, and comprehensive communication about infection prevention strategies.

\section{Study quality assessment}

Of 181 cross-sectional studies, scores ranged from 1 $(n=1,0.6 \%)[86]$ to $9(n=4,2.2 \%)[128,140,188,201]$ with a median score of 5 (Additional File 4). Twentyeight studies justified their sample size [54, 59, 70]. The majority of studies did not compare between respondents and non-respondents $(n=159,87.8 \%)$ or include $95 \%$ confidence intervals $(n=100,55.2 \%)$. The five included cohort studies $[55,57]$ had scores ranging from 4 $(n=1,20 \%)$ to $6(n=4,80 \%$. Only one described the ascertainment of exposure [55]. The six included qualitative studies [56, 72, 74, 115, 204, 209] were considered to be of sufficient methodological quality. One study had a pre-test, post-test study design and was considered to be of sufficient methodological quality [112].

\section{Discussion}

In this rapid review, we summarized the literature from 193 studies on physician experiences and management of psychological symptoms during infectious disease outbreaks. Results were consistent, with over 90,000 physicians surveyed during and after seven different infectious disease outbreaks (SARS, H7N9, H5N1, H1N1, MERS, Ebola, COVID-19) in 57 countries over the last 17 years. The burden of psychological symptoms in physicians was high, with anxiety symptoms affecting as many as $92.3 \%$ [210] of physicians and symptoms of PTSD in as many as 75.2\% [145]. Female, younger, more junior physicians were reported to be at higher risk of more symptoms and/or more severe symptoms, as were those physicians who were in direct contact with infected patients. Though, these associations should be interpreted with caution as future prospective studies are needed to confirm the associations between demographic variables/career stage of physicians and adverse psychological symptoms. Worry about their families being infected during the outbreak was the greatest source of physician psychological symptoms. Concerns about the availability and use of PPE predominated the distress of family physicians. How physicians managed psychological symptoms was highly variable and included tangible acts such as self-isolating away from family, following protocols, and receiving emotional support from family members. Some experts estimate that the pandemic could continue for much longer- at least 24 months [211]. Given the magnitude and long-term projection of the COVID-19 pandemic, and the number of physicians involved, the impact on performance, burnout, quality of life, and personal relationships could be large.

COVID-19 is affecting physicians through infection, psychological symptoms, and an interplay between the two. COVID-19 appears to affect older individuals disproportionately [212-214] and biological sex is associated with higher COVID-19 disease severity and death rates in males $[213,215]$. The physician workforce may be disproportionately affected by COVID-19; $20 \%$ of healthcare workers in Italy [216] had COVID-19 and China's National Health Commission reports that over 3300 healthcare workers have been infected as of early March [217]. To some extent this describes the healthcare workforce of many specialities directly caring for patients with COVID-19 in hospital, including critical care, emergency, and infectious disease medicine [218- 
220]. In contrast, family medicine, which may be the first point of medical contact for many patients, is a specialty with a greater proportion of female physicians [221]. The results of this rapid review suggest that who manifests psychological symptoms during this infectious disease outbreak may differ by age and specialty. Younger, more junior physicians (i.e., residents) are at greater risk of developing psychological symptoms during infectious disease outbreaks. Residency training programs should ensure psychological support for trainees caring for patients during COVID-19.

Further to the above recommendation, this review offers important learnings that individual physicians and health systems can use to immediately inform their understanding and management of physicians' psychological symptoms during an infectious disease outbreak. First, physicians should take up and apply the knowledge that psychological symptoms are common across the medical profession, manifest in various ways (e.g., anxiety vs. fear) and have specific triggers (e.g., close work with infected patients) in their day-to-day lives. For instance, this conceptualization should be used to help normalize experiences of psychological symptoms in oneself, enable recognition of symptoms in colleagues, and catalyze open dialogue around mental health and wellbeing across physician groups. Second, health systems must immediately prioritize the development of short and long-term supports for individual physicians, both in terms of recognition (e.g., education of psychological signs and symptoms) and treatment (e.g., online supports) options [222]. While some health systems have already begun to prioritize this type of programming $[223,224]$, there is much more that can be done to further these efforts [225]. As the impact is differential based off of area of practice (i.e., direct contact with infected patients) systems should focus their efforts on those physicians at the front lines of the pandemic. Finally, it is reasonable to extrapolate from this review that health systems should implement a long-term planning process to tackle some of the larger issues identified as triggers of physician psychological symptoms during an infectious disease outbreak, including options for appropriate accommodation away from family members when treating high-risk patients, and accessible training and access to PPE for all family physicians.

A major strength of our rapid review is the timely synthesis of evidence for physicians, health systems, and policy makers on physician psychological symptoms during the COVID-19 pandemic. This rapid review followed established standards [21], which included a comprehensive literature search in multiple databases and full-text review, data extraction, and quality assessments performed independently, and in duplicate. No restrictions were placed on language of publication, and we were able to capture literature from many countries affected by recent infectious disease outbreaks (e.g., China, Singapore, Hong Kong, United States, Canada). While the review by Kisely and colleagues [9] previously summarized psychological effects on healthcare workers overall, our review reports on more recent publications and compares the outcomes of the COVID-19 pandemic with previous infectious disease outbreaks. Our review also focuses on physicians, who may be uniquely impacted during infectious disease outbreaks as they are required to take on a high level of responsibility with patient care. As with all rapid reviews there are limitations to consider. It is possible some studies were missed in the search, though results were consistent in all included studies, regardless of the country or infectious disease outbreak. We restricted our search to include selected infectious disease outbreaks and, as such, the results may not be generalizable to other outbreaks (e.g., HIV/AIDS). Due to the rapid nature of this review, we restricted our search to physicians and therefore the results may not be generalizable to other healthcare workers, such as nurses or allied health professionals. The strategies described to manage physician psychological symptoms are anecdotal (i.e., self-reported strategies) and further studies are needed to test their effectiveness. The evidence was predominately the result of cross-sectional surveys, though in the rapidly changing context of infectious disease outbreaks this is likely the most feasible study design to employ.

\section{Conclusion}

This rapid review demonstrates that the burden of psychological symptoms in physicians during an infectious disease outbreak is high; half of physicians experience anxiety and one in five experience symptoms of PTSD. Physicians should be aware that psychological symptoms during an infectious disease outbreak are common, manifest in different ways, and have specific triggers. Health systems must prioritize psychological supports for physicians during and after infectious disease outbreaks and outside of outbreaks, plan to tackle the issues that place physicians at greatest risk.

\section{Supplementary Information}

The online version contains supplementary material available at https://doi. org/10.1186/s12888-021-03090-9.

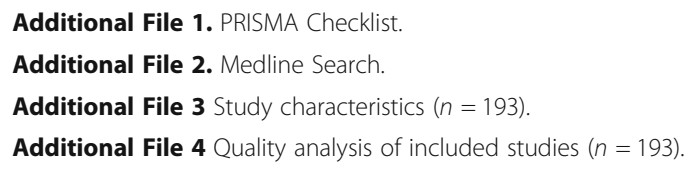

Acknowledgements

KMF confirms that she has full access to all the data in the study and had final responsibility for the decision to submit for publication. 


\section{Authors' contributions}

All authors made significant contributions to the conception and design of the work and the acquisition, analysis, or interpretation of the data. KMF, JPL, KK, and KP drafted the work and all authors (KMF, JPL, KDK, KMP, LGK, JNK, HTS) revised for important intellectual content. All authors (KMF, JPL, KDK, KMP, LGK, JNK, HTS) have given approval of the version to be published and agree to be accountable for all aspects of the work in ensuring that questions related to the accuracy or integrity of any part of the work are appropriately investigated and resolved.

\section{Funding}

This rapid review is funded by the Canadian Institutes of Health ResearchCanadian 2019 Novel Coronavirus (COVID-2019) Rapid Research Funding Opportunity- Operating Grant (Grant Number RN420046-439965) to JPL.

\section{Availability of data and materials}

The datasets used and/or analysed during the current study are available from the corresponding author on reasonable request.

\section{Ethics approval and consent to participate}

Not applicable.

\section{Consent for publication}

Not applicable.

\section{Competing interests}

The authors declare that they have no competing interests.

\section{Author details}

'Department of Critical Care Medicine, Cumming School of Medicine, University of Calgary \& Alberta Health Services, 3134 Hospital Drive NW Calgary T2N4Z6, Canada. ${ }^{2}$ Department of Community Health Sciences, Cumming School of Medicine, University of Calgary, 3134 Hospital Drive NW, Calgary T2N4Z6, Canada. ${ }^{3} \mathrm{O}$ 'Brien Institute for Public Health, Cumming School of Medicine, University of Calgary, 3134 Hospital Drive NW, Calgary, Alberta T2N4Z6, Canada. ${ }^{4}$ School of Health Administration, Faculty of Health and Department of Critical Care Medicine, Faculty of Medicine, Dalhousie University, 5850 College Street, Halifax, Nova Scotia B3H4R2, Canada.

\section{Received: 25 August 2020 Accepted: 2 February 2021}

\section{Published online: 10 February 2021}

\section{References}

1. Khot WY, Nadkar MY. The 2019 novel coronavirus outbreak - a global threat. J Assoc Physicians India. 2020;68(3):67-71.

2. Cascella M, Rajnik M, Cuomo A, Dulebohn SC, Di Napoli R. Features, evaluation and treatment coronavirus (COVID-19). Treasure Island: StatPearls; 2020

3. Bedford J, Enria D, Giesecke J, Heymann DL, Ihekweazu C, Kobinger G, et al. COVID-19: towards controlling of a pandemic. Lancet. 2020;395(10229): 1015-8.

4. Lai CC, Shih TP, Ko WC, Tang HJ, Hsueh PR. Severe acute respiratory syndrome coronavirus 2 (SARS-CoV-2) and coronavirus disease-2019 (COVID 19): the epidemic and the challenges. Int J Antimicrob Agents. 2020;55(3): 105924

5. Xiang Y, Yang Y, Li W, Zhang L, Zhang Q, Cheung T, et al. Timely mental health care for the 2019 novel coronavirus outbreak is urgently needed. Lancet Psychiatry. 2020;7(3):228-9.

6. Li W, Yang Y, Liu Z, Zhao Y, Zhang $Q$, Zhang L, et al. Progression of menta health services during the COVID-19 outbreak in China. Int J Biol Sci. 2020; 16(10):1732-8

7. Payne B, Bellamy R. Novel respiratory viruses: what should the clinician be alert for? Clin Med (Lond). 2014;14(Suppl 6):s12-6.

8. Adams JG, Walls RM. Supporting the health care workforce during the COVID-19 global epidemic. JAMA. 2020;323(15):1439-40.

9. Kisely S, Warren N, McMahon L, Dalais C, Henry I, Siskind D. Occurrence, prevention, and management of the psychological effects of emerging virus outbreaks on healthcare workers: rapid review and meta-analysis. BMJ. 2020;369:m1642

10. Berardo L, Gerges C, Wright J, Stout A, Shah H, Papanastassiou A, et al. Assessment of burnout prevention and wellness programs for US-based neurosurgical faculty and residents: a systematic review of the literature. J Neurosurg. 2020:1-9.

11. Sanfilippo F, Palumbo GJ, Noto A, Pennisi S, Minieri M, Vasile F, et al. Prevalence of burnout among intensive care physicians: a systematic review. Rev Bras Ter Intensiva. 2020;32(3):458-67.

12. Cheung $R$, Yu B, lordanous $Y$, Malvankar-Mehta MS. The prevalence of occupational burnout among ophthalmologists: a systematic review and meta-analysis. Psychol Rep. 2020:33294120954135.

13. Zhou AY, Panagioti M, Esmail A, Agius R, Van Tongeren M, Bower P. Factors associated with burnout and stress in trainee physicians: a systematic review and meta-analysis. JAMA Netw Open. 2020;3(8):e2013761.

14. Zaed I, Jaaiddane Y, Chibbaro S, Tinterri B. Burnout among neurosurgeons and residents in neurosurgery: a systematic review and meta-analysis of the literature. World Neurosurg. 2020;143:e529-e34.

15. Zhang Q, Mu MC, He Y, Cai ZL, Li ZC. Burnout in emergency medicine physicians: a meta-analysis and systematic review. Medicine (Baltimore). 2020:99(32):e21462

16. Lamothe M, Boujut E, Zenasni F, Sultan S. To be or not to be empathic: the combined role of empathic concern and perspective taking in understanding burnout in general practice. BMC Fam Pract. 2014;15:15.

17. Grace MK, VanHeuvelen JS. Occupational variation in burnout among medical staff: evidence for the stress of higher status. Soc Sci Med. 2019;232: 199-208.

18. El-Sherbiny E, Khashaba E, Abdel-Hady A. Burnout among intensive care workers in a tertiary care hospital in Saudi Arabia. Egypt J Occup Med. 2017; 41(2):289-306.

19. Pasricha T. The BMJ opinion [Internet]. Bmj, editor2020. [cited 2020]. Available from: https://blogs.bmj.com/bmj/2020/07/08/covid-19-will-endbut-doctors-will-keep-dying-supporting-physicians-mental-health-after-thepandemic/.

20. Abbasi J. Prioritizing physician mental health as COVID-19 marches on. JAMA. 2020:323(22):2235-6.

21. Tricco AC, Antony J, Zarin W, Strifler L, Ghassemi M, Ivory J, et al. A scoping review of rapid review methods. BMC Med. 2015;13:224.

22. Moher D, Liberati A, Tetzlaff J, Altman DG, Group P. Preferred reporting items for systematic reviews and meta-analyses: the PRISMA statement. BMJ. 2009;339:b2535

23. Antony J, Zarin W, Pham B, Nincic V, Cardoso R, Ivory JD, et al. Patient safety initiatives in obstetrics: a rapid review. BMJ Open. 2018;8(7):e020170

24. Tricco AC, Antony J, Straus SE. Systematic reviews vs. rapid reviews: what's the difference? : CADTH Rapid Review Summit. 2015. https://www.cadth.ca/ sites/default/files/events/Andrea-Tricco_RR-vs-Systematic-Reviews_Feb-4-201 5.pdf. Accessed 20 July 2020

25. Modesti PA, Reboldi G, Cappuccio FP, Agyemang C, Remuzzi G, Rapi S, et al Panethnic differences in blood pressure in Europe: a systematic review and meta-analysis. PLoS One. 2016;11(1):e0147601.

26. Wells GA, Shea B, O'Connell D, Peterson J, Welch V, Losos M, et al. The Newcastle-Ottawa Scale (NOS) for assessing the quality of nonrandomised studies in meta-analyses. 2013. http://www.ohri.ca/programs/clinical epidemiology/oxford.asp. Accessed 20 July 2020

27. The Joanna Briggs Institute. Checklist for Qualitative Research: Joanna Briggs Institute. 2020. https://jbi.global/critical-appraisal-tools. Accessed 20 July 2020.

28. Abdessater M, Rouprêt M, Misrai V, Matillon X, Gondran-Tellier B, Freton L, et al. COVID19 pandemic impacts on anxiety of French urologist in training: outcomes from a national survey. Prog Urol. 2020;30(8-9):448-55.

29. Abebe TB, Bhagavathula AS, Tefera YG, Ahmad A, Khan MU, Belachew SA, et al. Healthcare professionals' awareness, knowledge, attitudes, perceptions and beliefs about Ebola at Gondar University Hospital, Northwest Ethiopia: A cross-sectional study. J Public Health Afr. 2016;7(2).

30. Al Sulais E, Mosli M, AlAmeel T. The psychological impact of COVID-19 pandemic on physicians in Saudi Arabia: a cross-sectional study. Saudi J Gastroenterol. 2020;26(5):249-55.

31. Alsubaie S, Hani Temsah M, Al-Eyadhy AA, Gossady I, Hasan GM, Al-Rabiaah $A$, et al. Middle East respiratory syndrome coronavirus epidemic impact on healthcare workers' risk perceptions, work and personal lives. J Infect Dev Ctries. 2019;13(10):920-6

32. Amerio A, Bianchi D, Santi F, Costantini L, Odone A, Signorelli C, et al. Covid-19 pandemic impact on mental health: a web-based cross-sectional survey on a sample of Italian general practitioners. Acta Biomed. 2020;91(2): $83-8$ 
33. Austria-Corrales F, Cruz-Valdes B, Herrera-Kiengelher L, Garcia-Vazquez JC, Salas-Hernandez J. Burnout syndrome among Mexican physicians in training during a health emergency influenza virus A H1N1. Gac Med Mex. 2011; 147(2):97-103.

34. Badahdah A, Khamis F, Al Mahyijari N, Al Balushi M, Al Hatmi H, Al Salmi I, et al. The mental health of health care workers in Oman during the COVID19 pandemic. Int J Soc Psychiatry. 2020:20764020939596.

35. Yalçın Bahat P, Aldıkaçtıoğlu Talmaç M, Bestel A, Topbas Selcuki NF, Karadeniz O, Polat I. Evaluating the effects of the COVID-19 pandemic on the physical and mental well-being of obstetricians and gynecologists in Turkey. Int J Gynaecol Obstet. 2020;151(1):67-73.

36. Bohlken J, Schömig F, Seehagen T, Köhler S, Gehring K, Roth-Sackenheim C, et al. Experience of practice-based psychiatrists and neurologists during the COVID-19 pandemic. Psychiatr Prax. 2020;47(4):214-7.

37. Büntzel J, Klein M, Keinki C, Walter S, Büntzel J, Hübner J. Oncology services in corona times: a flash interview among German cancer patients and their physicians. J Cancer Res Clin Oncol. 2020;146(10):2713-5.

38. Cai W, Lian B, Song X, Hou T, Deng G, Li H. A cross-sectional study on mental health among health care workers during the outbreak of Corona Virus Disease 2019. Asian J Psychiatr. 2020;51:102111.

39. Chan AOM, Huak CY. Psychological impact of the 2003 severe acute respiratory syndrome outbreak on health care workers in a medium size regional general hospital in Singapore. Occup Med. 2004;54(3):190-6.

40. Chatterjee SS, Bhattacharyya R, Bhattacharyya S, Gupta S, Das S, Banerjee BB. Attitude, practice, behavior, and mental health impact of COVID-19 on doctors. Indian J Psychiatry. 2020;62(3):257-65.

41. Civantos AM, Byrnes Y, Chang C, Prasad A, Chorath K, Poonia SK, et al. Mental health among otolaryngology resident and attending physicians during the COVID-19 pandemic: national study. Head Neck. 2020;42(7):1597-609.

42. Dimitriu MCT, Pantea-Stoian A, Smaranda AC, Nica AA, Carap AC, Constantin $V D$, et al. Burnout syndrome in Romanian medical residents in time of the COVID-19 pandemic. Med Hypotheses. 2020;144:109972.

43. El Gaafary MM, Abd Elaziz KM, Abdel-Rahman AG, Allam MF. Concerns, perceived impacts and preparedness of health care workers in a referral hospital in Egypt in facing influenza (H1N1) epidemic. J Prev Med Hyg. 2010;51(3):105-9.

44. Elbay RY, Kurtulmuş A, Arpacıoğlu S, Karadere E. Depression, anxiety, stress levels of physicians and associated factors in Covid-19 pandemics. Psychiatry Res. 2020;290:113130.

45. Gill S, Hao D, Hirte H, Campbell A, Colwell B. Impact of COVID-19 on Canadian medical oncologists and cancer care: Canadian Association of Medical Oncologists survey report. Curr Oncol. 2020;27(2):71-4.

46. Grace SL, Hershenfield K, Robertson E, Stewart DE. The occupational and psychosocial impact of SARS on academic physicians in three affected hospitals. Psychosomatics. 2005;46(5):385-91.

47. Guiroy A, Gagliardi M, Coombes N, Landriel F, Zanardi C, Camino Willhuber G, et al. COVID-19 impact among spine surgeons in Latin America. Glob Spine J. 2020:2192568220928032.

48. Halayem S, Sayari N, Cherif W, Cheour M, Damak R. How Tunisian physicians of public health hospitals deal with COVID-19 pandemic: perceived stress and coping strategies. Psychiatry Clin Neurosci. 2020;74(9):496-7.

49. Huang JZ, Han MF, Luo TD, Ren AK, Zhou XP. Mental health survey of 230 medical staff in a tertiary infectious disease hospital for COVID-19. Zhonghua Lao Dong Wei Sheng Zhi Ye Bing Za Zhi. 2020;38(0):E001.

50. Khanna RC, Honavar SG, Metla AL, Bhattacharya A, Maulik PK. Psychological impact of COVID-19 on ophthalmologists-in-training and practising ophthalmologists in India. Indian J Ophthalmol. 2020;68(6):994-8.

51. Khattab MF, Kannan TMA, Morsi A, Al-Sabbagh Q, Hadidi F, Al-Sabbagh MQ, et al. The short-term impact of COVID-19 pandemic on spine surgeons: a cross-sectional global study. Eur Spine J. 2020;29(8):1806-12.

52. Khusid JA, Weinstein CS, Becerra AZ, Kashani M, Robins DJ, Fink LE, et al. Well-being and education of urology residents during the COVID-19 pandemic: results of an American National Survey. Int J Clin Pract. 2020; 74(9):e13559.

53. Koh D, Lim MK, Chia SE, Ko SM, Qian F, Ng V, et al. Risk perception and impact of severe acute respiratory syndrome (SARS) on work and personal lives of healthcare workers in Singapore: what can we learn? Med Care. 2005;43(7):676-82

54. Lai J, Ma S, Wang Y, Cai Z, Hu J, Wei N, et al. Factors associated with mental health outcomes among health care workers exposed to coronavirus disease 2019. JAMA Netw Open. 2020;3(3):e203976.
55. Li W, Frank E, Zhao Z, Chen L, Wang Z, Burmeister M, et al. Mental health of young physicians in China during the novel coronavirus disease 2019 outbreak. JAMA Netw Open. 2020;3(6):e2010705.

56. Liu Q, Luo D, Haase JE, Guo Q, Wang XQ, Liu S, et al. The experiences of health-care providers during the COVID-19 crisis in China: a qualitative study. Lancet Glob Health. 2020;8(6):e790-e8.

57. Lung F-W, Lu Y-C, Chang Y-Y, Shu B-C. Mental symptoms in different health professionals during the SARS attack: a follow-up study. Psychiatry Q. 2009; 80(2):107-16.

58. Mishra D, Nair AG, Gandhi RA, Gogate PJ, Mathur S, Bhushan P, et al. The impact of COVID-19 related lockdown on ophthalmology training programs in India - outcomes of a survey. Indian J Ophthalmol. 2020;68(6):999-1004.

59. Naser AY, Dahmash EZ, Al-Rousan R, Alwafi H, Alrawashdeh HM, Ghoul I, et al. Mental health status of the general population, healthcare professionals, and university students during 2019 coronavirus disease outbreak in Jordan: a cross-sectional study. Brain Behav. 2020

60. Naser MA. Evaluation of the level of anxiety among Iranian multiple sclerosis fellowships during the outbreak of COVID-19. Arch Iran Med. 2020;23(4):283.

61. Nickell LA, Crighton EJ, Tracy CS, Al-Enazy H, Bolaji Y, Hanjrah S, et al. Psychosocial effects of SARS on hospital staff: survey of a large tertiary care institution. Cmaj. 2004;170(5):793-8.

62. Odedra D, Chahal BS, Patlas MN. Impact of COVID-19 on Canadian radiology residency training programs. Can Assoc Radiol J. 2020;71(4):482-9.

63. Podder I, Agarwal K, Datta S. Comparative analysis of perceived stress in dermatologists and other physicians during national lock-down and COVID19 pandemic with exploration of possible risk factors: a web-based crosssectional study from eastern India. Dermatol Ther. 2020;33(4):e13788.

64. Poon E, Liu KS, Cheong DL, Lee CK, Yam LYC, Tang WN. Impact of severe acute respiratory syndrome on anxiety levels of frontline health care workers. Hong Kong Med J. 2004;10(5):325-30.

65. Que J, Shi L, Deng J, Liu J, Zhang L, Wu S, et al. Psychological impact of the COVID-19 pandemic on healthcare workers: a cross-sectional study in China. Gen Psychiatr. 2020;33(3):e100259.

66. Rodriguez RM, Medak AJ, Baumann BM, Lim S, Chinnock B, Frazier R, et al. Academic emergency medicine physicians' anxiety levels, stressors, and potential stress mitigation measures during the acceleration phase of the COVID-19 pandemic. Acad Emerg Med. 2020;27(8):700-7.

67. Sahu D, Agrawal T, Rathod V, Bagaria V. Impact of COVID 19 lockdown on orthopaedic surgeons in India: a survey. J Clin Orthop Trauma. 2020; 11(Suppl 3):S283-s90.

68. Shao Y, Zhang W. Psychological and ocular surface state of ophthalmologists and ophthalmic nurses working with patients with coronavirus disease 2019. JAMA Ophthalmol. 2020;138(8):907-10.

69. Sharif S, Amin F, Hafiz M, Benzel E, Peev N, Dahlan RH, et al. COVID 19depression and neurosurgeons. World Neurosurg. 2020;140:e401-e10.

70. Shechter A, Diaz F, Moise N, Anstey DE, Ye S, Agarwal S, et al. Psychological distress, coping behaviors, and preferences for support among New York healthcare workers during the COVID-19 pandemic. Gen Hosp Psychiatry. 2020;66:1-8.

71. Sil A, Das A, Jaiswal S, Jafferany M, Thole A, Rajeev R, et al. Mental health assessment of frontline COVID-19 dermatologists: A Pan-Indian multicentric cross-sectional study. Dermatol Ther. 2020:e13884.

72. Smith MW, Smith PW, Kratochvil CJ, Schwedhelm S. The psychosocial challenges of caring for patients with Ebola virus disease. Health Secur. 2017;15(1):104-9.

73. Song X, Fu W, Liu X, Luo Z, Wang R, Zhou N, et al. Mental health status of medical staff in emergency departments during the coronavirus disease 2019 epidemic in China. Brain Behav Immun. 2020;88:60-5.

74. Tan N, Goh L, Lee S. Family physicians' experiences, behaviour, and use of personal protection equipment during the SARS outbreak in Singapore: do they fit the Becker health belief model? Asia Pac J Public Health. 2006;18(3): 49-56.

75. Tang L, Pan L, Yuan L, Zha L. Prevalence and related factors of posttraumatic stress disorder among medical staff members exposed to H7N9 patients. Int J Nurs Sci. 2017;4(1):63-7.

76. Tham KY, Tan YH, Loh OH, Tan WL, Ong MK, Tang HK. Psychological morbidity among emergency department doctors and nurses after the SARS outbreak. Hong Kong J Emerg Med. 2005;12(4):215-23.

77. Thomaier L, Teoh D, Jewett P, Beckwith H, Parsons H, Yuan J, et al. Emotional health concerns of oncology physicians in the United States: fallout during the COVID-19 pandemic. PLoS One. 2020;15(11):e0242767. 
78. Tolomiczenko GS, Kahan M, Ricci M, Strathern L, Jeney C, Patterson K, et al. SARS: coping with the impact at a community hospital. J Adv Nurs. 2005; 50(1):101-10.

79. Tzeng HM, Yin CY. A crisis: fear toward a possible H5n1 pandemic. J Nurs Care Qual. 2008;23(2):177-83.

80. Urooj U, Ansari A, Siraj A, Khan S, Tariq H. Expectations, fears and perceptions of doctors during Covid-19 Pandemic. Pak J Med Sci. 2020; 36(Covid19-s4):S37-s42.

81. Verma S, Mythily S, Chan YH, Deslypere JP, Teo EK, Chong SA. Post-SARS psychological morbidity and stigma among general practitioners and traditional Chinese medicine practitioners in Singapore. Ann Acad Med Singap. 2004;33(6):743-8.

82. Wong WCW, Lee A, Tsang KK, Wong SYS. How did general practitioners protect themselves, their family, and staff during the SARS epidemic in Hong Kong? J Epidemiol Community Health. 2004;58(3):180-5.

83. Wong TW, Yau JK, Chan CL, Kwong RS, Ho SM, Lau CC, et al. The psychological impact of severe acute respiratory syndrome outbreak on healthcare workers in emergency departments and how they cope. Eur J Emerg Med. 2005;12(1):13-8.

84. Wong WCW, Wong SYS, Lee A, Goggins WB. How to provide an effective primary health care in fighting against severe acute respiratory syndrome: the experiences of two cities. Am J Infect Control. 2007;35(1):50-5.

85. Wong TY, Koh GC, Cheong SK, Sundram M, Koh K, Chia SE, et al. A crosssectional study of primary-care physicians in Singapore on their concerns and preparedness for an avian influenza outbreak. Ann Acad Med Singap. 2008;37(6):458-64.

86. Wu J, Chen X, Yao S, Liu R. Anxiety persists after recovery from acquired COVID-19 in anaesthesiologists. J Clin Anesth. 2020;67:109984.

87. Zerbini G, Ebigbo A, Reicherts P, Kunz M, Messman H. Psychosocial burden of healthcare professionals in times of COVID-19 - a survey conducted at the University Hospital Augsburg. Ger Med Sci. 2020;18:Doc05.

88. Zhang C, Yang L, Liu S, Ma S, Wang Y, Cai Z, et al. Survey of insomnia and related social psychological factors among medical staff involved in the 2019 novel coronavirus disease outbreak. Front Psychiatry. 2020;11:306.

89. Zhu J, Sun L, Zhang L, Wang H, Fan A, Yang B, et al. Prevalence and influencing factors of anxiety and depression symptoms in the first-line medical staff fighting against COVID-19 in Gansu. Front Psychiatry. 2020;11: 386.

90. Collins C, Mahuron K, Bongiovanni T, Lancaster E, Sosa JA, Wick E. Stress and the surgical resident in the COVID-19 pandemic. J Surg Educ. 2020;25:25.

91. Demirjian NL, Fields BKK, Song C, Reddy S, Desai B, Cen SY, et al. Impacts of the coronavirus disease 2019 (COVID-19) pandemic on healthcare workers: a nationwide survey of United States radiologists. Clin Imaging. 2020;68:21825.

92. Fargen KM, Leslie-Mazwi TM, Klucznik RP, Wolfe SQ, Brown P, Ansari SA, et al. The professional and personal impact of the coronavirus pandemic on US neurointerventional practices: a nationwide survey. J Neurolnterventional Surg. 2020;12(10):927-31

93. Fitzpatrick K, Patterson R, Morley K, Stoltzfus J, Stankewicz H. Physician wellness during a pandemic. West J Emerg Med. 2020;24.

94. Gokdemir O, Pak H, Bakola M, Bhattacharya S, Hoedebecke K, Jelastopulu E. Family physicians' knowledge about and attitudes towards COVID-19 - a cross-sectional multicentric study. Infect Chemother. 2020;21:21.

95. Huffman EM, Athanasiadis DI, Anton NE, Haskett LA, Doster DL, Stefanidis D, et al. How resilient is your team? Exploring healthcare providers' well-being during the COVID-19 pandemic. Am J Surg. 2020.

96. Jha S, Shah S, Calderon MD, Soin A, Manchikanti L. The effect of covid-19 on interventional pain management practices: A physician burnout survey. Pain Physician. 2020;23(4 Special Issue):S271-S82.

97. Johnson SU, Ebrahimi OV, Hoffart A. PTSD symptoms among health workers and public service providers during the COVID-19 outbreak. PLoS One. 2020;15(10 October).

98. Kannampallil TG, Goss CW, Evanoff BA, Strickland JR, McAlister RP, Duncan J. Exposure to COVID-19 patients increases physician trainee stress and burnout. PLoS One. 2020;15(8 August).

99. Kelker H, Yoder K, Musey P, Harris M, Johnson O, Sarmiento E, et al. Longitudinal prospective study of emergency medicine provider wellness across ten academic and community hospitals during the initial surge of the COVID-19 pandemic. Res Square. 2020;15:15.

100. Khalafallah AM, Lam S, Gami A, Dornbos DL, Sivakumar W, Johnson JN, et al. A national survey on the impact of the COVID-19 pandemic upon burnout and career satisfaction among neurosurgery residents. J Clin Neurosci. 2020; 80:137-42.

101. Khalafallah AM, Lam S, Gami A, Dornbos DL, Sivakumar W, Johnson JN, et al. Burnout and career satisfaction among attending neurosurgeons during the COVID-19 pandemic. Clin Neurol Neurosurg. 2020;198 (no pagination).

102. Rajan S, Bebawy J, Avitsian R, Lee CZ, Rath G, Luoma A, et al. The impact of the global SARS-CoV-2 (COVID-19) pandemic on neuroanesthesiology fellowship programs worldwide and the potential future role for ICPNT accreditation. J Neurosurg Anesthesiol. 2020;16:16.

103. Robbins JB, England E, Patel MD, DeBenedectis CM, Sarkany DS, Heitkamp DE, et al. COVID-19 impact on well-being and education in radiology residencies: a survey of the Association of Program Directors in Radiology. Acad Radiol. 2020;27(8):1162-72.

104. Schwartz DA, Connerney MA, Davila-Molina M, Tummalapalli SL. Resident mental health at the epicenter of the COVID-19 pandemic. Acad Med. 2020; 25:25.

105. Shah S, Castro-Dominguez Y, Gupta T, Attaran R, Byrum GV 3rd, Taleb A, et al. Impact of the COVID-19 pandemic on interventional cardiology training in the United States. Catheter Cardiovasc Interv. 2020;96(5):9971005.

106. Shalhub S, Mouawad NJ, Malgor RD, Johnson AP, Wohlauer MV, Coogan SM, et al. Global vascular surgeons' experience, stressors, and coping during the coronavirus disease 2019 pandemic. J Vasc Surg. 2020.

107. Sharma M, Creutzfeldt CJ, Lewis A, Patel PV, Hartog C, Jannotta GE, et al. Healthcare professionals' perceptions of critical care resource availability and factors associated with mental well-being during COVID-19: results from a US survey. Clin Infect Dis. 2020;02.

108. Cai H, Tu B, Ma J, Chen L, Fu L, Jiang Y, et al. Psychological impact and coping strategies of frontline medical staff in Hunan between January and March 2020 during the outbreak of coronavirus disease 2019 (COVID-19) in Hubei, China. Med Sci Monit. 2020;26:e924171.

109. Juan Y, Yuanyuan C, Qiuxiang Y, Cong L, Xiaofeng L, Yundong Z, et al. Psychological distress surveillance and related impact analysis of hospital staff during the COVID-19 epidemic in Chongqing, China. Compr Psychiatry. 2020;103 (no pagination).

110. Li G, Miao J, Wang H, Xu S, Sun W, Fan Y, et al. Psychological impact on women health workers involved in COVID-19 outbreak in Wuhan: a crosssectional study. J Neurol Neurosurg Psychiatry. 2020;91(8):895-7.

111. Liu Y, Wang L, Chen L, Zhang X, Bao L, Shi Y. Mental health status of paediatric medical workers in China during the COVID-19 outbreak. Front Psychiatry. 2020;11 (no pagination).

112. Liu Z, Wu J, Shi X, Ma Y, Ma X, Teng Z, et al. Mental health status of healthcare workers in China for COVID-19 epidemic. Ann Glob Health. 2020; 86(1):128.

113. Ning X, Yu F, Huang Q, Li X, Luo Y, Huang Q, et al. The mental health of neurological doctors and nurses in Hunan Province, China during the initial stages of the COVID-19 outbreak. BMC Psychiatry. 2020;20(1):436.

114. Wang H, Huang D, Huang H, Zhang J, Guo L, Liu Y, et al. The psychological impact of covid-19 pandemic on medical staff in guangdong, china: A cross-sectional study. Psychol Med. 2020:No Pagination Specified.

115. Xu Z, Ye Y, Wang Y, Qian Y, Pan J, Lu Y, et al. Primary care practitioners' barriers to and experience of COVID-19 epidemic control in China: a qualitative study. J Gen Intern Med. 2020.

116. Yang X, Zhang Y, Li S, Chen X. Risk factors for anxiety of otolaryngology healthcare workers in Hubei province fighting coronavirus disease 2019 (COVID-19). Soc Psychiatry Psychiatr Epidemiol. 2020;12.

117. Zhao X, Zhang T, Li B, Yu X, Ma Z, Cao L, et al. Job-related factors associated with changes in sleep quality among healthcare workers screening for 2019 novel coronavirus infection: a longitudinal study. Sleep Med. 2020;75:21-6.

118. Wang Y, Li Y, Jiang J, Feng Y, Lu D, Zhang W, et al. COVID-19 outbreakrelated psychological distress among healthcare trainees: a cross-sectional study in China. BMJ Open. 2020;10(10):e041671.

119. Bajaj J, Solanki S. Study of risk factors and psychological impact in physicians diagnosed with COVID-19: An online, postexposure, crosssectional survey. J Anaesthesiol Clin Pharmacol. 2020;36(3):345-9.

120. Banerjee S, Sarkar S, Bandyopadhyay SN. Survey and analysis of knowledge, attitude and practice among otolaryngologists in a state in eastern India in relation to the coronavirus disease 2019 pandemic. J Laryngol Otol. 2020; 134(8):696-702.

121. Barik S, Paul S, Kandwal P. Insight into the changing patterns in clinical and academic activities of the orthopedic residents during COVID-19 pandemic: 
a cross-sectional survey. Knee Surg Sports Traumatol Arthrosc. 2020;28(10): 3087-93.

122. Das A, Sil A, Jaiswal S, Rajeev R, Thole A, Jafferany M, et al. A study to evaluate depression and perceived stress among frontline Indian doctors combating the COVID-19 pandemic. Prim Care Companion CNS Disord. 2020;22(5).

123. Gangakhedkar G, Solanki S. Impact of the COVID-19 pandemic on anesthesiologists in India: a cross-sectional online survey of the practices, preparedness, and mind-set. J Anaesthesiol Clin Pharmacol. 2020;36(3):331-6,

124. Gupta S, Prasad AS, Dixit PK, Padmakumari P, Gupta S, Abhisheka K. Survey of prevalence of anxiety and depressive symptoms among 1124 healthcare workers during the coronavirus disease 2019 pandemic across India. Med J Armed Forces India. 2020;01:01.

125. Kapila AK, Schettino M, Farid Y, Ortiz S, Hamdi M. The impact of coronavirus disease 2019 on plastic surgery training: the resident perspective. Plast Reconstr Surg Glob Open. 2020;8(7):e3054.

126. Khasne RW, Dhakulkar BS, Mahajan HC, Kulkarni AP. Burnout among healthcare workers during COVID-19 pandemic in India: results of a questionnaire-based survey. Indian J Crit Care Med. 2020;24(8):664-71.

127. Pandey U, Corbett G, Mohan S, Reagu S, Kumar S, Farrell T, et al. Anxiety, depression and behavioural changes in junior doctors and medical students associated with the coronavirus pandemic: a cross-sectional survey. J Obstet Gynecol India. 2020.

128. Singariya G, Kamal M, Kumar M, Jain A, Solanki RK. COVID-19 pandemic: psychological impact on anaesthesiologists. Indian J Anaesth. 2020;64(9): 774-83.

129. Suryavanshi N, Kadam A, Dhumal G, Nimkar S, Mave V, Gupta A, et al. Mental health and quality of life among healthcare professionals during the COVID-19 pandemic in India. Brain Behav. 2020.

130. Uvais NA, Shihabudheen P, Hafi NAB. Perceived stress and stigma among doctors working in COVID-19-designated hospitals in India. Prim Care Companion CNS Disord. 2020;22(4).

131. Sarma R, Vig S, Rathore P, Pushpam D, Mishra S, Gupta N, et al. Concerns of health care professionals managing non-COVID patients during the COVID19 pandemic: a descriptive cross- sectional study. Indian J Palliat Care. 2020; 26(Suppl 1):S21-S6.

132. Saurabh K, Ranjan S. Preparedness, perceived impact and concerns of health care workers in a teaching hospital during coronavirus disease 2019 (COVID-19). J Fam Med Prim Care. 2020:9(8):4247-51.

133. Alhaj AK, Al-Saadi T, Mohammad F, Alabri S. Neurosurgery residents' perspective on COVID-19: knowledge, readiness, and impact of this pandemic. World Neurosurg. 2020;139:e848-e58.

134. Bitonti G, Palumbo AR, Gallo C, Rania E, Saccone G, De Vivo V, et al. Being an obstetrics and gynaecology resident during the COVID-19: impact of the pandemic on the residency training program. Eur J Obstet Gynecol Reprod Biol. 2020;253:48-51.

135. Buselli R, Corsi M, Baldanzi S, Chiumiento M, Del Lupo E, Dell'Oste V, et al. Professional quality of life and mental health outcomes among health care workers exposed to Sars-Cov-2 (Covid-19). Int J Environ Res Public Health [Electronic Resource]. 2020;17(17):26.

136. Di Monte C, Monaco S, Mariani R, Di Trani M. From resilience to burnout: psychological features of Italian general practitioners during COVID-19 emergency. Front Psychol. 2020;11:567201.

137. Vanni G, Materazzo M, Santori F, Pellicciaro M, Costesta M, Orsaria P, et al. The effect of coronavirus (COVID-19) on breast cancer teamwork: a multicentric survey. In Vivo. 2020;34:1685-94.

138. Sio SD, Buomprisco G, Torre GL, Lapteva E, Perri R, Greco E, et al. The impact of COVID-19 on doctors' well-being: results of a web survey during the lockdown in Italy. Eur Rev Med Pharmacol Sci. 2020;24(14):7869-79.

139. Caliskan F, Dost B. The evaluation of knowledge, attitudes, depression and anxiety levels among emergency physicians during the COVID-19 pandemic. Signa Vitae. 2020;16(1):163-71.

140. Hacimusalar Y, Kahve AC, Yasar AB, Aydin MS. Anxiety and hopelessness levels in COVID-19 pandemic: a comparative study of healthcare professionals and other community sample in Turkey. J Psychiatr Res. 2020; 129:181-8.

141. Korkmaz S, Kazgan A, Cekic S, Tartar AS, Balci HN, Atmaca M. The anxiety levels, quality of sleep and life and problem-solving skills in healthcare workers employed in COVID-19 services. J Clin Neurosci. 2020;80:131-6.

142. Kurt O, Deveci SE, Oguzoncul AF. Levels of anxiety and depression related to covid-19 among physicians: An online cross-sectional study from turkey. Ann Clin Anal Med. 2020;11(Supplement 3):S288-S93.
143. Ta SB, Ozceylan G, Ozturk GZ, Toprak D. Evaluation of job strain of family physicians in COVID-19 pandemic period- an example from Turkey. J Community Health. 2020;14:14.

144. Uyaroglu OA, Basaran NC, Ozisik L, Karahan S, Tanriover MD, Guven GS, et al. Evaluation of the effect of COVID-19 pandemic on anxiety severity of physicians working in the internal medicine department of a tertiary care hospital: a cross-sectional survey. Intern Med J. 2020.

145. Sahin MK, Aker S, Sahin G, Karabekiroglu A. Prevalence of depression, anxiety, distress and insomnia and related factors in healthcare workers during COVID19 pandemic in Turkey. J Community Health. 2020;45(6):1168-77.

146. Saracoglu KT, Simsek T, Kahraman S, Bombaci E, Sezen O, Saracoglu A, et al. The psychological impact of COVID-19 disease is more severe on intensive care unit healthcare providers: a cross-sectional study. Clin Psychopharmacol Neurosci. 2020;18(4):607-15.

147. An Y, Bellato V, Konishi T, Pellino G, Sica GS, Kefleyesus A, et al. Surgeons' fear of getting infected by COVID19: a global survey. Br I Surg. 2020;107(11): e543-e4.

148. Azoulay E, De Waele J, Ferrer R, Staudinger T, Borkowska M, Povoa P, et al. Symptoms of burnout in intensive care unit specialists facing the COVID-19 outbreak. Ann Intensive Care. 2020;10(1).

149. Bhargava S, Sarkar R, Kroumpouzos G. Mental distress in dermatologists during COVID-19 pandemic: assessment and risk factors in a global, crosssectional study. Dermatol Ther. 2020

150. Louie PK, Harada GK, McCarthy MH, Germscheid N, Cheung JPY, Neva MH, et al. The impact of COVID-19 pandemic on spine surgeons worldwide. Glob Spine J. 2020;10(5):534-52.

151. O'Kelly F, Sparks S, Seideman C, Gargollo P, Granberg C, Ko J, et al. A survey and panel discussion of the effects of the COVID-19 pandemic on paediatric urological productivity, guideline adherence and provider stress. J Pediatr Urol. 2020;16(4):492.e1-9.

152. Weiner JA, Swiatek PR, Johnson DJ, Louie PK, Harada GK, McCarthy MH, et al. Spine surgery and COVID-19: the influence of practice type on preparedness, response, and economic impact. Glob Spine J. 2020.

153. Sayari AJ, Harada GK, Louie PK, McCarthy MH, Nolte MT, Mallow GM, et al. Personal health of spine surgeons can impact perceptions, decision-making and healthcare delivery during the COVID-19 pandemic-a worldwide study. Neurospine. 2020;17(2):313-30.

154. Schmulson M, Gudino-Zayas M, Hani A. The impact of COVID-19 pandemic on Neurogastroenterologists in Latin America: results of an online survey. J Clin Gastroenterol. 2020.

155. Pilar A, Gravel SB, Croke J, Soliman H, Chung P, Wong RKS. Coronavirus disease 2019's (COVID-19's) silver lining-through the eyes of radiation oncology fellows. Adv Radiat Oncol. 2020;23:23.

156. Kramer V, Papazova I, Thoma A, Kunz M, Falkai P, Schneider-Axmann T, et al. Subjective burden and perspectives of German healthcare workers during the COVID-19 pandemic. Eur Arch Psychiatry Clin Neurosci. 2020.

157. Ayub M, Arshad D, Magbool N, Zahid M, Malik RS, Rizvi ZA, et al. Physicians' attitudes towards treating patients in the context of COVID-19 pandemic in Pakistan. Cureus. 2020:12(9):e10331.

158. Bakry AMA, Sobhy E, Abdelmohty H. Cardiac surgeons between apprehension and ethical duty in the COVID-19 pandemic. Asian Cardiovasc Thorac Ann. 2020.

159. Tan YQ, Chan MT, Chiong E. Psychological health among surgical providers during the COVID-19 pandemic: a call to action. Br J Surg. 2020;107(11): e459-e60.

160. Cotrin P, Moura W, Gambardela-Tkacz CM, Pelloso FC, Santos LD, Carvalho MDB, et al. Healthcare workers in Brazil during the COVID-19 pandemic: a cross-sectional online survey. Inquiry. 2020;57:46958020963711.

161. de Wit K, Mercuri M, Wallner C, Clayton N, Archambault P, Ritchie K, et al. Canadian emergency physician psychological distress and burnout during the first 10 weeks of COVID-19: a mixed-methods study. J Am Coll Emerg Physicians Open. 2020;26:26.

162. Enyama D, Chelo D, Noukeu Njinkui D, Mayouego Kouam J, Fokam Djike Puepi Y, Mekone Nkwele I, et al. Impact of the COVID-19 pandemic on pediatricians' clinical activity in Cameroon. Arch Pediatr. 2020.

163. Florin M, Pinar U, Chavigny E, Bouaboula M, Jarboui L, Coulibaly A, et al. Socio-economic and psychological impact of the COVID-19 outbreak on private practice and public hospital radiologists. Eur J Radiol. 2020;132 (no pagination)

164. Foley DA, Chew R, Raby E, Tong SYC, Davis JS, Australasian Society for Infectious Diseases Clinical Research N. COVID-19 in the pre-pandemic period: 
a survey of the time commitment and perceptions of infectious diseases physicians in Australia and New Zealand. Intern Med J. 2020;50(8):924-30.

165. Norton EJ, Georgiou I, Fung A, Nazari A, Bandyopadhyay S, Saunders KEA. Personal protective equipment and infection prevention and control: a national survey of UK medical students and interim foundation doctors during the COVID-19 pandemic. J Public Health. 2020;23.

166. Kuo FL, Yang PH, Hsu HT, Su CY, Chen CH, Yeh IJ, et al. Survey on perceived work stress and its influencing factors among hospital staff during the COVID-19 pandemic in Taiwan. Kaohsiung J Med Sci. 2020.

167. Khattab MF, Abou-Madawi AM. Current effect of COVID-19 global pandemic on the professional and life profiles of the Egyptian spine surgeons. Sicotj. 2020;6:31.

168. Osama M, Zaheer F, Saeed H, Anees K, Jawed Q, Syed SH, et al. Impact of COVID-19 on surgical residency programs in Pakistan; a residents' perspective. Do programs need formal restructuring to adjust with the "new normal"? A cross-sectional survey study. Int J Surg. 2020;79:252-6.

169. Rajwa P, Przydacz M, Zapala P, Wieckiewicz G, Ryszawy J, Choragwicki D, et al. How has the COVID-19 pandemic impacted polish urologists? Results from a national survey. Cent Eur J Urol. 2020;73(3):252-9.

170. Rymarowicz J, Stefura T, Major P, Szeliga J, Wallner G, Nowakowski M, et al. General surgeons' attitudes towards COVID-19: a national survey during the SARS-CoV-2 virus outbreak. Eur Surg Acta Chir Austriaca. 2020.

171. Saadeh RA, Alfaqih M, Younis OB, Okour A, Obeidat K. The psychosocial and clinical concerns of physicians treating COVID-19 patients. J Taibah Univ Med Sci. 2020;23:23.

172. Sanghavi PB, Au Yeung K, Sosa CE, Veesenmeyer AF, Limon JA, Vijayan V. Effect of the coronavirus disease 2019 (COVID-19) pandemic on pediatric resident well-being. J Med Educ Curric Dev. 2020;7:2382120520947062.

173. Degraeve A, Lejeune S, Muilwijk T, Poelaert F, Piraprez M, Svistakov I, et al. When residents work less, they feel better: lessons learned from an unprecedent context of lockdown. Prog Urol. 2020;08.

174. Abdulah DM, Mohammed AA. The consequences of the COVID-19 pandemic on perceived stress in clinical practice: experience of doctors in Iraqi Kurdistan. Rom J Intern Med. 2020;03.

175. Abdulah DM, Musa DH. Insomnia and stress of physicians during COVID-19 outbreak. Sleep Med. 2020;2 (no pagination).

176. Almater A, Tobaigy M, Younis A, Alaqeel M, Abouammoh M. Effect of 2019 coronavirus pandemic on ophthalmologists practicing in Saudi Arabia: a psychological health assessment. Middle East Afr J Ophthalmol. 2020;27(2):79-85.

177. Alnofaiey $\mathrm{YH}$, Alshehri HA, Alosaimi MM, Alswat SH, Alswat RH, Alhulayfi RM, et al. Sleep disturbances among physicians during COVID-19 pandemic. BMC Res Notes. 2020;13(1):493.

178. Arshad AR, Islam F. COVID-19 and anxiety amongst doctors: a Pakistani perspective. J Coll Physicians Surg Pakistan : JCPSP. 2020;30(10):106-9.

179. Civantos AM, Bertelli A, Goncalves A, Getzen E, Chang C, Long Q, et al. Mental health among head and neck surgeons in Brazil during the COVID19 pandemic: a national study. Am J Otolaryngol. 2020;41(6).

180. Gallopeni F, Bajraktari I, Selmani E, Tahirbegolli IA, Sahiti G, Muastafa A, et al. Anxiety and depressive symptoms among healthcare professionals during the Covid-19 pandemic in Kosovo: A cross sectional study. J Psychosom Res. 2020;137 (no pagination)

181. Giardino DL, Huck-Iriart C, Riddick M, Garay A. The endless quarantine: the impact of the COVID-19 outbreak on healthcare workers after three months of mandatory social isolation in Argentina. Sleep Med. 2020;76:16-25.

182. Hasan SR, Hamid Z, Jawaid MT, Ali RK. Anxiety among doctors during COVID-19 pandemic in secondary and tertiary care hospitals. Pak J Med Sci. 2020;36(6):1360-5.

183. Imran N, Masood HMU, Ayub M, Gondal KM. Psychological impact of COVID-19 pandemic on postgraduate trainees: a cross-sectional survey. Postgrad Med J. 2020;25

184. Jo SH, Koo BH, Seo WS, Yun SH, Kim HG. The psychological impact of the coronavirus disease pandemic on hospital workers in Daegu, South Korea. Compr Psychiatry. 2020;103 (no pagination).

185. Milgrom Y, Tal Y, Finestone AS. Comparison of hospital worker anxiety in COVID-19 treating and non-treating hospitals in the same city during the COVID-19 pandemic. Isr J Health Policy Res. 2020;9(1).

186. Ruiz-Fernandez MD, Ramos-Pichardo JD, Ibanez-Masero O, CabreraTroya J, Carmona-Rega MI, Ortega-Galan AM. Compassion fatigue, burnout, compassion satisfaction, and perceived stress in healthcare professionals during the COVID-19 health crisis in Spain. J Clin Nurs. 2020;28.
187. Shah N, Raheem A, Sideris M, Velauthar L, Saeed F. Mental health amongst obstetrics and gynaecology doctors during the COVID-19 pandemic: results of a UK-wide study. Eur J Obstet Gynecol Reprod Biol. 2020;253:90-4.

188. Vallee M, Kutchukian S, Pradere B, Verdier E, Durbant E, Ramlugun D, et al. Prospective and observational study of COVID-19's impact on mental health and training of young surgeons in France. Br J Surg. 2020;107(11):e486-e8.

189. Naser AY, Dahmash EZ, Al-Rousan R, Alwafi H, Alrawashdeh HM, Ghoul I, et al. Mental health status of the general population, healthcare professionals, and university students during 2019 coronavirus disease outbreak in Jordan: a cross-sectional study. medRxiv. 2020.

190. Chatterjee SS, Bhattacharyya R, Bhattacharyya S, Gupta S, Das S, Banerkee BB. Attitude, practive, behavior, and mental health impact of COVID-19 on doctors. Indian J Psychiatry. 2020;62(3):257-65.

191. Amin F, Sharif S, Saeed R, Durrani N, Jilani D. COVID-19 pandemicknowledge, perception, anxiety and depression among frontline doctors of Pakistan. BMC Psychiatry. 2020;20(1).

192. Fekih-Romdhane F, Snene H, Jebri A, Ben Rhouma M, Cheour M. Psychological impact of the Pandemic COVID-19 Outbreak Among Medical Residents in Tunisia. Asian J Psychiatr. 2020;53 (no pagination).

193. Elhadi M, Msherghi A. Mental health of surgeons during the COVID-19 pandemic: An urgent need for intervention. Surgery. 2020.

194. Elkholy H, Tawfik F, Ibrahim I, Salah El-Din W, Sabry M, Mohammed S, et al. Mental health of frontline healthcare workers exposed to COVID-19 in Egypt: a call for action. Int J Soc Psychiatry. 2020;20764020960192.

195. Guillen-Astete C, Penedo-Alonso R, Gallego-Rodriguez P, Carballo-Cardona C, Estevez-Rueda MJ, Galli-Cambiaso E, et al. Levels of anxiety and depression among emergency physicians in Madrid during the sars-cov-2 pandemic. [Spanish]. Emergencias. 2020;32(5):369-73.

196. Hilmi M, Boileve A, Ducousso A, Michalet M, Turpin A, Neuzillet C, et al. Professional and psychological impacts of the COVID-19 pandemic on oncology residents: a national survey. JCO Glob Oncol. 2020;6:1674-83.

197. Ali H, Ismail AA, Abdalwahab A. Mental stress in anesthesia and intensive care physicians during COVID-19 outbreak. Anesthesiol Pain Med. 2020; 10(5):1-6.

198. Mohd Fauzi MF, Mohd Yusoff H, Muhamad Robat R, Mat Saruan NA, Ismail KI, Mohd Haris AF. Doctors' mental health in the Midst of COVID-19 pandemic: the roles of work demands and recovery experiences. Int J Environ Res Public Health [Electronic Resource]. 2020;17(19):08.

199. Li L, Wu C, Gan Y, Qu X, Lu Z. Insomnia and the risk of depression: a metaanalysis of prospective cohort studies. BMC Psychiatry. 2016;16(1):375.

200. Neckelmann D, Mykletun A, Dahl AA. Chronic insomnia as a risk factor for developing anxiety and depression. Sleep. 2007;30(7):873-80.

201. Monterrosa-Castro A, Redondo-Mendoza V, Mercado-Lara M. Psychosocial factors associated with symptoms of generalized anxiety disorder in general practitioners during the COVID-19 pandemic. J Investig Med. 2020;68(7): 1228-34.

202. Chew QH, Chia FLA, Ng WK, Lee WCl, Tan PLL, Wong CS, et al. Psychological and coping responses to COVID-19 amongst residents in training across ACGME-I accredited specialties in Singapore. Psychiatry Res. 2020;290 (no pagination).

203. Johnson AP, Wohlauer MV, Mouawad NJ, Malgor RD, Coogan SM, Sheahan MG 3rd, et al. The impact of the COVID-19 pandemic on vascular surgery trainees in the United States. Ann Vasc Surg. 2020;03:03.

204. Khot N, Kumar A. Flattening the anxiety curve: Obstetricians' response to the COVID-19 pandemic in Victoria. Aust N Z J Obstet Gynaecol. 2020;60(4):E10.

205. Malgor RD, Sobreira ML, Mouawad NJ, Johnson AP, Wohlauer MV, Coogan $\mathrm{SM}$, et al. Brazilian vascular surgeons experience during the coronavirus (COVID-19) pandemic. Vascular. 2020.

206. Mosheva M, Hertz-Palmor N, Dorman Ilan S, Matalon N, Pessach IM, Afek A, et al. Anxiety, pandemic-related stress and resilience among physicians during the COVID-19 pandemic. Depress Anxiety. 2020;37(10):965-71.

207. Coyle C, Ghazi H, Georgiou I. The mental health and well-being benefits of exercise during the COVID-19 pandemic: a cross-sectional study of medical students and newly qualified doctors in the UK. Ir J Med Sci. 2020.

208. Milgrom Y, Richter $V$. Stress assessment among internal medicine residents in a level-3 hospital versus a level-2 hospital with only emergency room service for COVID-19. J Community Hosp Intern Med Perspect. 2020;10(4): $301-5$.

209. Rashid A, Faisal K. Pandemic anxiety and its correlates among young doctors working frontline in Pakistan. Glob Mental Health. 2020; (no pagination). 
210. Arafa A, Mohammed Z, Mahmoud O, Elshazley M, Ewis A. Depressed, anxious, and stressed: what have healthcare workers on the frontlines in Egypt and Saudi Arabia experienced during the COVID-19 pandemic? J Affect Disord. 2021;278:365-71

211. Moroes KA, Lipsitch M, Barry JM, Osterholm MT. COVID-19: The CIDRAP Viewpoint Minneapolis, MN: Office of the Vice President for Research, University of Minnesota; 2020. Available from: https://www.cidrap.umn.edu/ covid-19/covid-19-cidrap-viewpoint.

212. Zhou F, Yu T, Du R, Fan G, Liu Y, Liu Z, et al. Clinical course and risk factors for mortality of adult inpatients with COVID-19 in Wuhan, China: a retrospective cohort study. Lancet. 2020;395(10229):1054-62.

213. Chen N, Zhou M, Dong X, Qu J, Gong F, Han Y, et al. Epidemiological and clinical characteristics of 99 cases of 2019 novel coronavirus pneumonia in Wuhan, China: a descriptive study. Lancet. 2020;395(10223):507-13.

214. Wang D, Hu B, Hu C, Zhu F, Liu X, Zhang J, et al. Clinical characteristics of 138 hospitalized patients with 2019 novel coronavirus-infected pneumonia in Wuhan, China. JAMA. 2020;323(11):1061-9.

215. Huang C, Wang Y, Li X, Ren L, Zhao J, Hu Y, et al. Clinical features of patients infected with 2019 novel coronavirus in Wuhan, China. Lancet. 2020;395(10223):497-506

216. Remuzzi A, Remuzzi G. COVID-19 and Italy: what next? Lancet; 2020

217. Lancet T. COVID-19: protecting health-care workers. Lancet. 2020;395(10228): 922.

218. Colleges AoAM. The state of women in academic medicine: the pipeline and pathways to leadership, 2015-2016. Washington, DC; 2016.

219. Leigh JP, Grood C, Ahmed SB, Ulrich AC, Fiest KM, Straus SE, et al. Toward gender equity in critical care medicine: a qualitative study of perceived drivers, implications, and strategies. Crit Care Med. 2019;47(4):e286-e91.

220. The Lancet Infectious D. Gender parity in infectious diseases. Lancet Infect Dis. 2019:19(3):217.

221. Information ClfH. Physicians in Canada, 2018. Ottawa; 2019.

222. Dewey C, Hingle S, Goelz E, Linzer M. Supporting clinicians during the COVID-19 pandemic. Ann Intern Med. 2020:172(11):752-3.

223. Chen Q, Liang M, Li Y, Guo J, Fei D, Wang L, et al. Mental health care for medical staff in China during the COVID-19 outbreak. Lancet Psychiatry. 2020;7(4):e15-e6.

224. Officer BCOotPH. Pandemic influenza psychosocial support plan for health care workers and providers - British Columbia's pandemic influenza response plan. British Columbia; 2012.

225. Sands P, Mundaca-Shah C, Dzau VJ. The neglected dimension of global security--a framework for countering infectious-disease crises. N Engl J Med. 2016:374(13):1281-7.

\section{Publisher's Note}

Springer Nature remains neutral with regard to jurisdictional claims in published maps and institutional affiliations.

Ready to submit your research? Choose BMC and benefit from:

- fast, convenient online submission

- thorough peer review by experienced researchers in your field

- rapid publication on acceptance

- support for research data, including large and complex data types

- gold Open Access which fosters wider collaboration and increased citations

- maximum visibility for your research: over $100 \mathrm{M}$ website views per year

At $\mathrm{BMC}$, research is always in progress.

Learn more biomedcentral.com/submissions 